\title{
Congenital pemphigus syphiliticus: a characteristic feature of a forgotten disease
}

\author{
Sakviseth Bin
}

Neonatal Intensive Care Unit, Calmette Hospital, Phnom Penh, Cambodia

\section{Correspondence to}

Dr Sakviseth Bin;

sakviseth_bin@yahoo.com

Accepted 23 September 2021

\section{DESCRIPTION}

The preterm male infant was delivered at $303 / 7$ weeks of gestational age by an emergency $\mathrm{C}$-section due to placenta previa, with haemorrhage and fetal distress. The mother, 21 years old, gravida 2 parity 1 , had no underlying diseases. The antenatal care was done regularly at a provincial health centre; syphilis and HIV were negative at the first prenatal visit in the first trimester. She was transferred to our tertiary centre for vaginal bleeding.

The birth weight was $1150 \mathrm{~g}$ (20th percentile), and the Apgar scores were $3 / 4 / 5$ at 1,5 and $10 \mathrm{~min}$, respectively. Pressure positive ventilation was given, and he was intubated at $3 \mathrm{~min}$ of life and transferred to the neonatal intensive care unit. Umbilical cord venous $\mathrm{pH}$ was 7 with lactate of $10 \mathrm{mmol} / \mathrm{L}$. Per unit protocol, septic screen was done, and empiric antibiotics were prescribed. Gastric aspirate and haemoculture (peripheral and from central line) were later shown to be negative. Initial blood tests showed a white blood cell count of $28.3 \times 10^{9} / \mathrm{L}$ with immature/total neutrophil ratio of 0.05 , severe anaemia (haemoglobin $105 \mathrm{~g} / \mathrm{L}$ ), platelets of $190 \times 10^{9} / \mathrm{L}$ and procalcitonin of $0.92 \mathrm{ng} / \mathrm{mL}$.

Due to the presence of hepatomegaly $(3 \mathrm{~cm}$ below the costal margin) and pemphigus on both feet (figure 1), syphilis tests, including Rapid Plasma Reagin (RPR) and Treponema Pallidum Hemagglutination (TPHA), were requested:

- The mother's titre : RPR 1:4, TPHA 1:640

- The infant's titre: RPR 1:4, TPHA 1:640

The diagnosis of maternal and congenital syphilis was made, and the antibiotics were changed to benzylpencillin at 3 hours of life. This case report illustrates a severe case of perinatal asphyxia, masking a congenital syphilis.

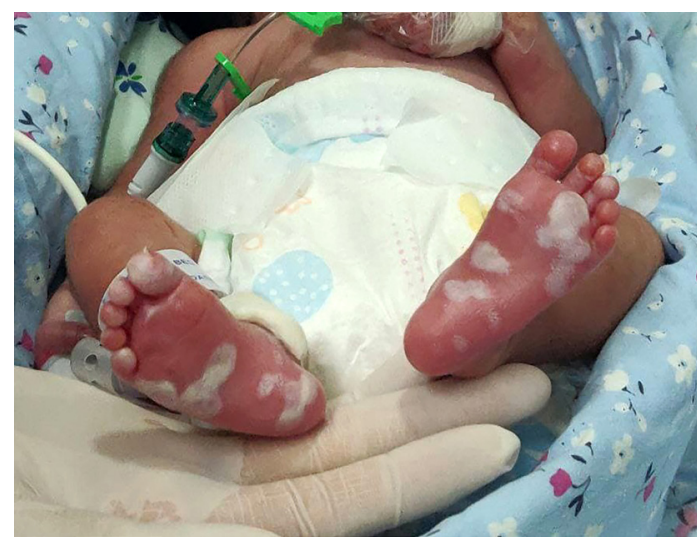

Figure 1 Pemphigus syphiliticus.

\section{Learning points}

- Congenital syphilis is severe but preventable with proper maternal screenings, leading to an early, timely and adequate treatment of maternal syphilis.

- Pemphigus syphiliticus is rare but pathognomonic, warranting a thorough physical examination of the newborn.

- The diagnosis tools and treatments are easily accessible and inexpensive in our economical settings.

Regretfully, the neonate died at 32 hours of life. He was on conventional ventilation for 12 hours (Synchronized Intermittent Mandatory Ventilation (SIMV)) and on High-Frequency Oscillation (HFO) for 20 hours. He got two transfusions of red blood cells.

Mother-to-child transmission of Treponema pallidum can occur during any stage of pregnancy. Fetal infection from untreated or inadequately treated maternal syphilis can lead to serious adverse birth outcomes, including fetal loss, stillbirth, early infant death, symptomatic infected newborns, premature delivery and low birth weight. ${ }^{1}$

Clinical features of early congenital syphilis are variable, and the neonates are mostly asymptomatic at birth. The most common manifestations are hepatomegaly, jaundice and skin rash; other symptoms include rhinitis, lymphadenopathies, central nervous invasion and bone involvement. ${ }^{2}$ The most prominent cutaneous lesions are copper-coloured, maculopapular rash, mostly on the palms and soles. Pemphigus syphiliticus is pathognomonic but rare. It is characterised by fluid-filled bullae, which appear mostly at the extremities and tend to rapidly peel and form crust. ${ }^{3}$

The diagnosis of congenital syphilis depends on multiple factors such as maternal serology, adequacy of her treatment, physical examination of the newborn and paired serology using nontreponemal tests such Rapid Plasma Reagin and Venereal Disease Research Laboratory. Penicillin $G$ remains the most effective spirochetocidal drug of choice. ${ }^{4}$

Congenital syphilis can be prevented by early diagnosis of maternal syphilis through repeated screenings and on-time and adequate treatment. It was also shown that even incomplete maternal 
penicillin therapy could reduce the risks of severe neonatal complications. ${ }^{5}$

Acknowledgements I would like to thank Prof. Sethikar IM for her advice and encouragement.

Contributors SB wrote the case report and performed the literature review on congenital syphilis. He communicated with the parents and got their consent for the publication.

Funding The authors have not declared a specific grant for this research from any funding agency in the public, commercial or not-for-profit sectors.

Competing interests None declared.

Patient consent for publication Consent obtained from parent(s)/guardian(s)

Provenance and peer review Not commissioned; externally peer reviewed.
ORCID iD

Sakviseth Bin http://orcid.org/0000-0003-2513-8690

\section{REFERENCES}

1 Gomez GB, Kamb ML, Newman LM, et al. Untreated maternal syphilis and adverse outcomes of pregnancy: a systematic review and meta-analysis. Bull World Health Organ 2013:91:217-26.

2 Bowen V, Su J, Torrone E, et al. Increase in incidence of congenital syphilis - United States, 2012-2014. MMWR Morb Mortal Wkly Rep 2015;64:1241-5.

3 Cooper JM, Sánchez PJ. Congenital syphilis. In: Seminars in Perinatology. . WB Saunders, 2018: 42. 176-84

4 Workowski KA, Bolan GA, Centers for Disease Control and Prevention. Sexually transmitted diseases treatment guidelines, 2015. MMWR Recomm Rep 2015;64:RR-03.

5 Lago EG. Current perspectives on prevention of mother-to-child transmission of syphilis. Cureus 2016;8:e525.

Copyright 2021 BMJ Publishing Group. All rights reserved. For permission to reuse any of this content visit

https://www.bmj.com/company/products-services/rights-and-licensing/permissions/

BMJ Case Report Fellows may re-use this article for personal use and teaching without any further permission.

Become a Fellow of BMJ Case Reports today and you can:

- Submit as many cases as you like

- Enjoy fast sympathetic peer review and rapid publication of accepted articles

- Access all the published articles

Re-use any of the published material for personal use and teaching without further permission

Customer Service

If you have any further queries about your subscription, please contact our customer services team on +44 (0) 2071111105 or via email at support@bmj.com.

Visit casereports.bmj.com for more articles like this and to become a Fellow 